\title{
THE INVESTOR RISK TOLERANCE AND MARKET LIQUIDITY CONNECTION: EVIDENCE FROM THE SELECTED MARKETS*
}

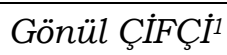 \\ Şükriye Gül REIS ${ }^{2}$
}

Citation/ (O: Çifçi, G. and Reis, Ş., G. (2021). The investor risk tolerance and market liquidity connection: evidence from the selected markets. Hitit Journal of Social Sciences, 14(2), 536-555. doi: 10.17218/ hititsbd. 1024411

Abstract: This study searched in what ways the stock market liquidity and the investor risk tolerance has a relation over the developed and developing countries. Seven developed and six developing countries were selected from the International Monetary Fund's counrty list for the sample. Dataset was consisted of the stock markets' weekly data. Some interesting results were found. The investors' risk tolerance and the market liquidity had a long-run relation in the all markets. The variables changed together. However, the cointegration regression coefficients were not same in the markets. The coefficients could be estimated just for the USA, UK and Indonesia within the confidence intervals. Neverthlessly, the variables did not have any short-run relation in spite of the long-run relation. Those results implied other variable(s) may cause a long-run relation between the tolerance and liquidity. Also, the variable(s) may affect the markets in different strength. It caused a positive and different degree relation in the USA and UK, while it was negative in Indonesia.

Keywords: Market liquidity, Liquidity risk, Amihud illiquidity ratio, Risk, Investor risk tolerance

\section{Yatırımcı Risk Toleransı ve Piyasa Likiditesi İlişkisi: Seçili Piyasalardan Bulgular}

Atıf/C: Çifçi, G., ve Reis, Ş., G. (2021).Yatırımcı risk toleransı ve piyasa likiditesi ilişkisi: seçili piyasalardan bulgular. Hitit Sosyal Bilimler Dergisi, 14(2), 536-555. doi: 10.17218/hititsbd.1024411

Özet: Bu çalışma, gelişmiş ve gelişmekte olan ülke piyasalarının likiditesi ile yatırımcı risk toleransının ne şekilde birbiri ile ilişkili olduğunu incelemiştir. Örneklem olarak Uluslararası Para Fonu' nun ülkeler listesinden yedi gelişmiş ve altı gelişmekte olan ülke seçilmiştir. Veri seti haftalık verileri kapsamaktadır. Çalışmadan enteresan sonuçlar bulunmuştur. Tüm piyasalarda, yatırımcı risk toleransı ile piyasa likiditesi arasında uzun dönemli bir ilişki bulunmuştur. Değişkenlerin birlikte hareket ettiği görülmüştür. Ancak eşbütünleşme regresyon katsayıları piyasalarda aynı değildir. Eşbütünleşme regresyon katsayısı, belirlenmiş güven aralığında, sadece Amerika, İngiltere ve Endonezya için tahmin edilebilmiştir. Ayrıca, uzun dönemli ilişkinin varlığına rağmen değişkenler arasında kısa dönemli bir ilişki bulunamamıştır. Bu sonuçlar, piyasa likiditesi ile yatırımcı risk toleransı arasında uzun dönemli ilişkiye yol açan başka değişken(ler) olabileceğini göstermektedir. Ayrıca bu değişken (değişkenler) piyasaları farklı düzey ve yönde etkilemiş olabilirler. Söz konusu

\section{Research Article}

Submitted: 16.11.2021 Accepted: 29.12.2021

*This study is derived from the doctoral thesis titled "Investor Risk Tolerance For Liquidity Risk In Capital Markets: Applications In Different Markets" and thesis number 626572, completed in 2020 by Gönül Çifçi under the supervision of Asst. Prof. Dr. Şükriye Gül Reis.

1 Correspoding Author, Research Assistant Dr., Adiyaman University, Faculty of Economics and Administrative Sciences, Adiyaman/ Turkey. gcifci@adiyaman.edu.tr, http://orcid.org/0000-0002-5788-7461

2 Assistant Professor Dr., Gaziantep University, Faculty of Economic and Administrative Sciences, Gaziantep/Turkey. greis@gantep.edu.tr, http://orcid.org/0000-0001-7654-4256 
The Investor Risk Tolerance and Market Liquidity Connection: Evidence from the Selected Markets

değişkenin (değişkenlerin) Amerika ve İngiltere'de pozitif yönlü ilişki sağlarken, Endonezya'da negatif yönlü bir ilişkiye yol açtığı gözlenmiştir.

Anahtar Kelimeler: Piyasa likiditesi, Likidite riski, Amihud likidite yetersizlik orant, Risk, Yatırmcı risk

\section{INTRODUCTION}

The risk is an indispensable factor which affects the financial markets and investors. It can be defined as possibility of loss or deviations from the expectations. Some people would like to stay away from the risks because of its connotations of negative feelings. The risk-avoidance behaviour can be related to people's attitudes besides possible losses and additional costs.

The risk is also a criterion for investment decisions. However, the risk attitude is important as far as the risk, because the people make investments based on their attitude borders. Therefore, the financial markets should monitor the investors' risk attitude to understand and forecast market trends.

According to Bernoulli (1954), The Expected Utility Theory, all investors are rational and these investors only use the information about the risk and return to make investments. However, that theory could not explain to abnormal movements in the markets. Black (1986) stated some investors are not rational and they are reasons of the abnormal movements. Those irrational investors were named as noise investors (or noise traders). The investors move depending on the noise and the noise which affects the risk attitudes can be emotions, intuitions or hints (Black, 1986, p. 536).

The investor risk-attitude can be called as the risk tolerance. The risk tolerance is an ambition to possibility of loss or the maximum risk level that one can bear. The maximum risk for the risk tolerance is either maximum loss level or minimum return level (Chou, 2014; Chiang and Xiao, 2017). Investors trade in financial markets with their risk tolerance, so the risk tolerance shows which instruments will be sold/ bought or which transaction will be cancelled. An important result of the cancelled or happened transaction seems on the liquidity levels of the markets.

The market liquidity is regarding to trade easiness, but cancelled transactions impair the liquidity. In circumstance of the cancellation, costs will rise, prices will change and transaction speeds will slow down. As a result, the market liquidity will decrease (Stange, 2009; Cumming et al., 2011; Castagna and Fede, 2013). Basicly, transactions are cancelled because of investors' behavioral reasons (such as future expectations, emotional factors, risk attitudes) or deficient liquidity (Ernst et al., 2009). There are some studies show the risk attidudes affect the market liquidity in some ways. Lee et al. (1991), Tetlock (2007) and Liu (2015) mentioned if the risk tolerance is high (riskattitude is positive) the liquidity will rise. However, Hacıhasanoğlu and Soytaş (2009) and Lin (2011) found the liquidity will decrease if the tolerance is high. Beyond those two different approaches, some studies concluded the liquidity can change the risk tolerance as well. Arrondel et al. (2010) and Blanchett et al. (2018) showed the market liquidity may change the investors' risk tolerances, as well.

In this study, that controversial relation of the risk tolerance and market liquidity will be searched in the different markets. It is expected to reach beneficial outputs for the literature and the financial markets by answering how the risk tolerance and market liquidity connects each other and whether their relations change on the markets.

The rest of paper proceeds as follows. In section 2, the theoretical framework of the market liquidity, risk tolerance and these two variables relation are explained. The section 3 discusses the existing literature on basis of the investor risk-attitude and market liquidity. The section 4 
defines the data and methodology of the study. In section 5, the findings of the econometric analysis are shared. The section 6 discusses the empirical results. Section 7 concludes the all results. Also, the limitations and importance of the study are explained in that section.

\section{THEORETICAL FRAMEWORK}

The market liquidity shows the ability of generating sufficient funds for all participants of the market. Therefore, it has been a desirable condition for all kinds of the financial markets.

Keynes (1936) expressed three related indicators to define the market liquidity in "Liquidity Preference" theory. Those are transaction speed, transaction volume and transaction costs. The transaction speed is a good indicator for the liquidity even the liquidity cannot be observed directly in the market (Subramanian and Jarrow, 2001; Cumming et al., 2011; Correa et al., 2015; Sun, 2016; Dahir et al., 2018; Castagna and Fede, 2013). It shows necessary trading time to sell a financial instrument in a market. Short trading time means transaction speed is high and the market is liquid enough. In liquid markets, financial instruments are sold in a short time and maybe can change by hands frequently (Cumming et al., 2011, p.660). In illiquid markets, transaction speed is slow because there are not enough funds for the transactions. Therefore, cancelled transactions are seen in the markets.

Also, transaction cost is a liquidity indicator. The traders may have to bear additional costs such as liquidity, cancelation and/or research costs because of cancelled transactions (Ernst et al., 2009; Stange, 2009). The costs are low and transaction volume is big in liquid markets. Bigvolume transactions happen just in liquid markets, the deficient funds lead the investors to smallvolume transactions. There is a serious liquidity problem, even if the small-volume transactions cannot happen in the market (Ajina et al., 2015; Farboodi and Veldkamp, 2017).

Based on those indicators liquid markets can be defined as the market which gives opportunity to trade financial instruments with high transaction speed and low costs in big volumes. Those indicators can affect the transaction prices, as well.

The transaction prices are equal to real prices in liquid markets. However, the illiquidity causes wide bid-ask spreads and maybe price volatility. So, the market possibly struggles with a liquidity risk if price spread is wide, transaction costs are high, transaction volume is small, and transaction speed is slow (Subramanian and Jarrow, 2001; Stange, 2009; Cumming et al., 2011; Castagna and Fede, 2013; Rui et al., 2016; Sun 2016; Farboodi and Veldkamp 2017; Dahir et al., 2018).

The risk can be measured with the probability calculations and expressed with the numbers. The numbers show what the risk level is and reflect to the risk objectively. However, individuals change the numbers' values on basis of their personal perceptions. That makes the risks subjective. Therefore, it can be said the risks have subjective and objective dimensions. Additionally, the investors can be grouped as objective and subjective investors based on their risk perceptions.

Bernoulli (1954) accepted all investors as objective in "The Expected Utility Theory". According to that theory, all investors show rational behaviours and choose more profitable investments. However, Black (1986) classified investors as rational (objective) and noise (subjective) investors. The future expectations, emotions and/ or social issues impact the noise investors' risk perceptions. Even though those investors cause speculations and additional risks, they are neccessary for the market liquidity. Noise investors continue to trade even in bad market 
conditions and that increases the market liquidity (Black, 1986; Apergis et al., 2017). Monitoring the noise investors' market actions will be helpful to reduce the risks and increase the liquidity.

The risk tolerance can be a good mesasure to monitor investors' behaviours in the markets. It is basicly the maximum uncertainty or risk level that individuals can accept while making financial decisions (Grable, 2000; Hurley, 2005; Franklin, 2007; Chou, 2014; Bernstein, 2015; Saraç and İskenderoğlu, 2016). It shapes investors' movements in the market and lead investors to find most suitable investments. Low-risk tolerance investors do not like risks, they cannot bear deviations and volatility, expect a certain investment earnings (Ausburg and Spremann, 1981; Frijns et al., 2013). Low-risk tolerance investors avoid risky markets and financial instruments. They may be reason of canceled transactions and that will make the liquidity problem worse in the markets.

High-risk tolerance investors would like to have more risk and prefer risky financial instruments, investments and markets (Markowitz, 1952; Frijns et al., 2013). They are especially important for the developing and undeveloped markets and also for the bad times of the developed markets. High-risk tolerance investors can accept the low earnings due to positive expections. They keep investing even in poor conditions of the markets and negative earning instruments as well. In that way, those investors can rise the market liquidity (Black, 1986; Tobin, 1958).

\section{LITERATURE REVIEW}

There are some studies show how the risk tolerance and market liquidity connects each others. Subrahmanyam (1991) found a positive relation between the market liquidity and risk tolerance. Another important result of the study is the insider traders' asymetric information can change the level of the liquidity and tolerance. The risk tolerance goes up and the insider traders become more aggressive in the markets when they have asymetric information. That causes a rise in the market liquidity. The other studies like Lee, Shleifer, and Thaler (1991), Kumar and Lee (2006), Baker and Wurgler (2006), Canbaş and Kandir (2009) showed if investors have risk-taking attitue the market liquidity will rise. Liu (2015) compared the relation on basis of individual and instituional investors on the NYSE and AMEX markets. The liquidity is mostly affected from the individual investors' risk tolerance both in the markets. Reis and Pinho (2021) searched the investor sentiment's effects on stock returns in the European companies. They concluded that the investor sentiment can affect the stock returns. The sentiment can be used to predict the returns. While the tolerance decreases (fear increase), the expected returns will down. That result implies the market liquidity will decrease because of expected prices and returns if the risk tolerance is low.

The other kinds of researches are about to how positive feed-backs and expectations or selfconfidencency of the investors' change the market liquidity. High-risk tolerance investors were defined as over-confident and fundemantalist (not positive feed-back) investors whose expectations are positive for the markets. Tetlock (2007), Garcia (2013), Liu (2015) concluded positive and negative statements make changes in the investors' risk tolerances. According to those studies, the investor risk tolerance and market liquidity increase if the positive sentences used in the media. Whereas, negative sentences make decrease the tolerance and liquidity. Dumas et al. (2009) demonstrated the over-confident investors will increase their risk tolerance when the future expectations are positive and that badly affects the market liquidity. Also, the risk tolerance may change with some emotional factors.

However, Hacıhasanoğlu and Soytaş (2009) and Deuskar and Johnson (2011) pointed out a negative relation between the tolerance and liquidity. Lin (2011) mentioned that high-risk tolerance investors make the market fragile to liquidity risk in the long run; on the other hand, 
low-risk tolerance investors impact the market liquidity temporarly. Simililary, Cheng and Kim (2017) found the risk tolerance causes price volatility in the markets.

Conversely, some studies show the market liquidity can change the risk tolerance levels. The different liquidity levels may attract different kinds of investors and it may change investors' risk tolerance levels, as well. Arrondel et al. (2010) said that investors have tendecy to lower their risk tolerance when the market is illiquid. Blanchett et al. (2018) found older investors change their risk tolerance levels when the S\&P 500 index prices change. If the prices are volatile or bid-ask spread is big, the market liquidity decreases and the investors shape their risk tolerance levels.

Based on the existing studies, it can be said that the different liquidity levels are good opportunity for the different kinds of investors. The liquid markets seem safe investment opportunity for the low-risk tolerance investors because the risks are lower. However, illiquid markets may seem as a bargain for the high-risk tolerance investors to get much more gain. Because of those possibilities investor can be motivated to trade more in either liquid or illiquid markets. Additionally, investors may remote their risk tolerance levels. The investors increase their risk tolerance if the future expectations are positive and decrease the tolerance if the future expectations are negative.

\section{DATA AND METHODOLOGY}

This study aims to answer some questions. In this part, the questions were defined. Afterwards, the variables, sample, data and methodology were explained.

\subsection{Research Problems and Hypothesis of the Study}

This study asks four questions about the investor risk tolerance and market liquidity. The first question is "Is there a relation between the investor risk tolerance and market liquidity?". That question is to understand the existence of the relation between the risk tolerance and market liquidity. Some searches such as Lee et al. (1991), Subrahmanyam (1991), Kumar and Lee (2006), Baker and Wurgler (2006), Tetlock (2007), Dumas et al. (2009), Canbaş and Kandır (2009), Garcia (2013), and Liu (2015) found a positive relation between the variables. Neverthlessly, Lin (2011) doubts that positive relation by demonstrating only high-risk tolerance investors have effects on the liquidity in the long-run. Moreover, Hacihasanoğlu and Soytaş (2009), Deuskar and Johnson (2011), and Cheng and Kim (2017) concluded there is an inverse relation between the variables. Those different results make ask the second question. "Is the relationship of the investor risk tolerance and market liquidity positive or negative?"

$H_{1}$ : The investor risk tolerance and market liquidity have a relation.

$H_{1 a}$ : The investor risk tolerance and market liquidity have a relation for short-run.

$H_{1 b}$ : The investor risk tolerance and market liquidity have a relation for long-run.

$H_{1 c}$ : The relationship of the investor risk tolerance and market liquidity is positive.

$H_{1 d}$ : The relationship of the investor risk tolerance and market liquidity is negative.

The thirth question is "Is the relation of the risk tolerance and market liquidity is one-way or twoways relationship?" The aim of that question is revealing the causality relation of the variables. The most of the studies mentioned the risk tolerance can change the market liquidity levels. However, Arrondel et al. (2010) and Blanchett et al. (2018) showed the market liquidity can change the risk tolerance level, as well.

$\mathrm{H}_{2}$ : There is a two-ways causality between the market liquidity and risk tolerance. 
The Investor Risk Tolerance and Market Liquidity Connection: Evidence from the Selected Markets

$H_{3}$ : There is a one-way causality between the market liquidity and risk tolerance.

$H_{3 a}$ : There is a causality from the risk tolerance to the market liquidity.

$H_{3 b}$ : There is a causality from the market liquidity to the risk tolerance.

The last question compares the markets depend on the relation degree. In other words, the question was asked to understand if the tolerance and liquidity relation shows same degree in all financial markets. To demonstrate it, that question was asked:

"Does the risk tolerance and market liquidity relation change across the different financial markets?"

$H_{4}$ : The degree of relationship between the investor risk tolerance and market liquidity is not different over the developed and developing country markets.

$H_{5}$ : The degree of relationship between the investor risk tolerance and market liquidity is different over the developed and developing country markets.

$H_{5 a}$ : The degree of relationship between the investor risk tolerance and market liquidity is higher in the developed country markets.

$H_{5 b}$ : The degree of relationship between the investor risk tolerance and market liquidity is higher in the developing country markets.

Fan and Xiao (2006) and Barasinska and Schafer (2017) showed investors' risk tolerances are different in the markets. Yıldırım (2011) implied the market liquidity' effects on the risk attitudes were not same in the financial markets of the USA and Turkey after the 2007 economic crisis. In this study, a two-ways and different level of the relation is expected on basis of those mentioned studies' results.

\subsection{Significance of the Study}

This study examines if the investor risk tolerance and market liquidity have a connection and the relation changes in the financial markets. In that point, this study is important because the existing studies do not give enough information about the relation. The useful outputs were expected about it. By having more information on the risk tolerance and market liquidity, markets can forecast how market liquidity may change with the risk tolerance or how the risk tolerance may change with the market liquidity. That also useful for predicting prices and returns.

Also, this study is the first research which compares the developed and developing countries' markets based on the liquidity and tolerance relation. This study will show differences and similarities between the markets.

\subsection{Sample}

The risk tolerance changes with some demographical factors such as age, sexuality, marital status, education level, income level, cultural factors, sexual equaility and social norms (Usul et al., 2002; Fan and Xiao, 2006; Kahyaoğlu, 2011; Jain and Mandot, 2012; Frinjs et al, 2013; Bannier and Neubert, 2016; Barasinska and Schafer, 2017; Muktadir-Al-Mukit, 2020). Some of those variables are used to determine the countries' development levels by International Monetary Fund (IMF). Therefore, the countries' development levels were preferred to compare the markets.

A sample was composed with seven developed and six developing countries. The countries were selected from the IMF's development lists. Table 1 shows the countries which involved in the sample and their market indices. 
Table1. Sample Countries and Market Indices

\begin{tabular}{llll}
\hline Developed Country & Market Index & Developing Country & Market Index \\
\hline Canada & S\&P/TSX Composite Index & Turkey & BIST 100 \\
Japan & NIKKIE 225 & Brazil & IBOVESPA \\
France & CAC 40 & Indonesia & JKLQ 45 \\
Germany & DAX Performance Index & India & NIFTY 50 \\
Italy & FTSE/MIB & South Africa & FTSE/ JSE 40 \\
UK & FTSE 100 & China & Shangai SE 50 \\
USA & NASDAQ 100 & & \\
\hline
\end{tabular}

The Turkey, Brazil, Indonesia, India, South Africa and China were selected for the developing countries because many of the other developing countries have the problems on the data access. The UK, USA, Japan, France, Germany, Italy, and Canada are the most developed countries in the IMF's list. However, there was a problem about those countries' financial markets. Those countries have at least two stock markets. The big-transaction volume markets of those countries were selected for the sample, since they may have more accurate data and investors.

\subsection{Data}

Two series were created as the market liquidity and risk tolerance on weekly basis for the econometric analysis. The data set covers daily market values from the 1th of January, 2008 to the 30th of July, 2019. It was impossible to get older data than 2008 for all the markets.

The sampled markets' trading days were not exactly same for everytime because of different holiday and working-days which would cause some problems in the analysis. To prevent the possible problems, the daily index values were converted to weekly data. Another issue was about the currency. Instead of a comman currency, every countries' own currencies were used in the analysis. In that way exchange differences of the countries could not affect the analysis. Also, local and global economic crises were ignored during the analysis.

Some problems were experienced while appraising the risk tolerance. The first problem is the covariance inverse matrix could not be calculated because the some expected additional returns were zero. The second problem is the determinants of the return covariance matrix were zero for the developing countries in December, 2018. Due to those two reasons, 45 observations were missing. The missing observations were generated with the panel missing data creation method and the observation numbers reached 7917 weekly data (3654 observations for the developing countries and 4263 observations for the developed countries).

\subsubsection{Market Liquidity Measure}

The market liquidity was measured with the Amihud (2002) illiquidity ratio. The Amihud (2002) illiquidity ratio defines the market liquidity as the return provided by one unit of transaction volume. It gives better results than the other liquidity measures and it is practical with accessible data (Ajina et al., 2015).Table 2 shows the variables' descriptions and denotations for the Amihud (2002) illiquidity ratio.

Table 2. Variable Description and Denotation-Market Liquidity

\begin{tabular}{ll}
\hline Variables/ Denotation & Description \\
\hline $\mathrm{i}$ & Index \\
$\mathrm{t}$ & Day \\
$P_{t}$ & Price in day $\mathrm{t}$ \\
$P_{t-1}$ & Price in day $\mathrm{t}-1$ \\
$R_{i t}$ & Return of index in day t \\
$\left|R_{i t}\right|$ & Absolute value of the return \\
$V O L_{i t}$ & Daily transaction volume \\
$D_{i d}$ & Number of trading days in the period \\
$I L L I Q_{i t}$ & Daily illiquidity ratio \\
$I L L I Q_{i d}$ & Weekly illiquidity ratio \\
\hline
\end{tabular}


The Investor Risk Tolerance and Market Liquidity Connection:

The daily returns are calculated as the first of the three steps. Equation (1) shows daily return calculation where is relied on the market prices $\left(P_{t}\right.$ and $\left.P_{t-1}\right)$.

$R_{i t}=100 x\left[\left(P_{t}\right)-\left(P_{t-1}\right)\right] /\left(P_{t-1}\right)$

After finding the return, illiquidity ratio $\left(I L L I Q_{i t}\right)$ can be calculated with equation (2). ILLIQ $Q_{i t}$ is the daily illiquidity ratio and shows how much returns can be generated by one unit of transaction volume.

$I L L I Q_{i t}=\left|R_{i t}\right| / V O L_{i t}$

$I L L I Q_{i d}=\frac{1}{D_{i d}} \sum_{d=1}^{D_{i d}} I L L I Q_{i t}$

An average illiquidity ratio also can be calculated with equation (3). $D_{i d}$ is the trading days number in the selected period and $I L L I Q_{i d}$ shows average illiquidity ratio.

\subsubsection{Investor Risk Tolerance Measure}

The investor risk tolerance measure was derived from Froot and O' Connell (2003). Froot and O' Connell (2003) created an index for international investors' risk tolerance as shown in equation (4). Equation (4) is a version of the investor demand function. The hat $(\wedge)$ notation shows log values.

$\widehat{\mathrm{Q}_{\mathrm{I}, \mathrm{j}}^{*}}=\left[\left(\widehat{\theta}_{\mathrm{I}}-\widehat{\theta}_{\mathrm{L}}\right)+(1-\gamma)\left(\widehat{\mathrm{W}}_{\mathrm{I}-} \widehat{\mathrm{W}}_{\mathrm{L}, \mathrm{j}}\right)+\left(\mathrm{v}_{\mathrm{I}, \mathrm{j}}-\mathrm{v}_{\mathrm{L}, \mathrm{j}}\right)\right] \frac{\mathrm{Q}_{\mathrm{L}, \mathrm{j}}}{\overline{\mathrm{Q}}_{\mathrm{J}}}$

This index has the ability to show the growth trend of the risk tolerance and it can be used instead of the GRAI index. The other advantage of the index is showing increases and decreases of the risk tolerance (Coudert and Gex, 2006). However, international investors' number and their origin is necessary for that index and finding these informations is almost impossible for the most of the markets. In this study, a new method derived from Froot and Q' Connell (2003)' s study. They defined the demand $\widehat{(D)}$ seen as in the equations (5) and (6).

$\widehat{D_{J}}=\widehat{Q_{J}}+\widehat{P}_{J}-\widehat{W}_{j}$

$\widehat{D_{J y}}=\widehat{\widehat{\theta}_{J y}}-\gamma_{j y} \widehat{W}_{j y}+\widehat{\sum_{j y}^{-1} \mu}$

The equation (5) and (6) should be equal as a basic mathematic rule. The equation (7) shows that equilibrium and it can be revised based on the risk tolerance, $\widehat{\hat{\theta}_{\mathrm{J}}}$.

$\widehat{Q_{J}}+\widehat{P}_{J}-\widehat{W}_{j}=\widehat{\hat{\theta}_{J y}}-\gamma_{j y} \widehat{W}_{j y}+\widehat{\sum_{J y}^{-1} \mu}$

The equation (8) shows the risk tolerance measure (index) which depends on the market prices, transaction volumes, risk aversion, country's and investor's wealths and returns. The table 3 gives variables descriptions and denotations for the investor risk tolerance index.

$\hat{\theta}_{j_{y}}=\widehat{Q_{J}}+\widehat{P}_{J}-\widehat{W}_{j}+\gamma_{j y} \widehat{W}_{j y}+\widehat{\sum_{j y}^{-1} \mu}$

Table 3. Variables and Denotation Description- Risk Tolerance

\begin{tabular}{ll}
\hline Variables/ Denotation & Description \\
\hline$\hat{\theta}_{j}$ & Investor risk tolerance \\
$Q_{j}$ & Demand in the market. Transaction volumes were used for it. \\
$P_{j}$ & Transaction price \\
$\widehat{W}_{j}$ & Country wealth.GDP values were used for it. To get weekly GDP values \\
$\widehat{W}_{j y}$ & annual GDPs were divided 52 (week number in a year). \\
$\gamma_{j y}^{-\mathbf{1}}$ & Investors' wealth. Market capitilization were expected as investor' s wealth. \\
$\sum_{j}$ & Risk aversion. It was estimated with CARA method. \\
& Inverse matrix of return. It is a percentage value which denotes the return \\
& covariance inverse matrix of the markets. \\
& Expected additional return vector. The $\mu$ is calculated by the CAPM model. \\
& For the risk-free interest rate. The weekly values of 10-years government \\
& bonds of the countries were used. Beta values of the markets are provided \\
\end{tabular}


In the equation 8 , jy means investor y in the country j. $\widehat{P}_{j}$ is the transaction price, $Q_{j}$ is the market demand, $\widehat{W}_{j}$ is the country' s wealth, $\widehat{W}_{j y}$ is the investor' s wealth, $\mu$ is the expected addititional return, $\gamma_{j y}$ is the risk aversion and $\Sigma_{j y}^{-1}$ is the inverse matrix of returns.

\section{RESULTS}

In this section, econometric analysis results were discussed. The panel data cointegration test, cointegration coefficient estimator and causality tests were applied. The unit root, autocorrelation, cross-sectional dependency, homogeneity and variance test results are represented in the Appendix. Table 4 shows the statistical summary of the market liquidity and the risk tolerance series.

Table 4. Descriptive Statistics

\begin{tabular}{lrrrr}
\hline & \multicolumn{2}{c}{ Market Liquidity } & \multicolumn{2}{c}{ Risk Tolerance } \\
& $\begin{array}{r}\text { Developing } \\
\text { Country } \\
\text { Markets }\end{array}$ & $\begin{array}{r}\text { Developed } \\
\text { Country Markets }\end{array}$ & $\begin{array}{r}\text { Developing } \\
\text { Country Markets }\end{array}$ & $\begin{array}{r}\text { Developed Country } \\
\text { Markets }\end{array}$ \\
\hline Average & -6.96 & -6.16 & 20.46 & 20.43 \\
Median & -8.64 & -8.92 & 14.95 & -13.47 \\
Maximum & -3.98 & -4.48 & 22.91 & -23.55 \\
Minimum & -10.9 & -10.9 & -21.96 & 21.8 \\
Standart Deviation & -5.75 & -5.61 & 21.48 & 4654 \\
Observation Number & 3654 & 4263 & 263 \\
\hline \hline
\end{tabular}

The market liquidities' maximum value has 0.5 differences between the market groups (it is -3.98 in the developed countries and -4.48 in the developing countries) while the minimum values are same and it is -10.90 . The average liquidity levels have a slight difference $(-6.16$ in the developed countries and -6.96 in the developing countries). The risk tolerances are almost same in both the developed (20.43) and the developing countries (20.46).

\subsection{Westerlund Cointegration Test}

The Westerlund (2006) is one of the cointegration tests in panel data analysis. It can be used even in stationary series at the first difference and gives more accurate results if $\mathrm{T}>\mathrm{N}$ (Westerlund, 2006; Doğanay and Değer, 2017).

It calculates two group averages and two panel averages both for homogenous $\left(P_{a}\right.$ and $\left.P_{t}\right)$ and heterogenous panels $\left(G_{a}\right.$ and $\left.G_{t}\right)$ (Erataş et al., 2013). The series are homogenous in this study, so $P_{a}$ and $P_{t}$ were used. The Westerlund cointegration test results are in the Table 5 .

Table 5. Westerlund Cointegration Test

\begin{tabular}{|c|c|c|c|c|c|c|c|c|c|}
\hline Developed Country & & $\operatorname{lag} 3$ & & & $\operatorname{lag} 9$ & & & $\operatorname{lag} 20$ & \\
\hline Statistic & value & Z-value & P-value & value & Z-value & P-value & value & Z-value & P-value \\
\hline $\mathrm{Pt}$ & -12.39 & -7.92 & ${ }^{*} 0.00$ & -8.14 & -2.98 & **0.00 & -6.26 & -0.78 & 0.22 \\
\hline $\mathrm{Pa}$ & -45.13 & -16.03 & ${ }^{*} 0.00$ & -28.8 & -8.79 & $* * 0.00$ & -22.87 & -6.16 & $* * * 0.00$ \\
\hline Developing Country & & $\operatorname{lag} 3$ & & & $\operatorname{lag} 9$ & & & $\operatorname{lag} 20$ & \\
\hline Statistic & value & Z-value & P-value & value & Z-value & P-value & value & Z-value & P-value \\
\hline Pt & -8.98 & -8.00 & ${ }^{*} 0.00$ & -5.07 & -3.45 & **0.00 & -5.07 & -3.45 & $* * * 0.00$ \\
\hline $\mathrm{Pa}$ & -235.57 & -37.94 & $* 0.00$ & -158.97 & -25.11 & ${ }^{* *} 0.00$ & -158.97 & -25.11 & $* * * 0.00$ \\
\hline
\end{tabular}

The cointegrations were calculated with 3, 9 and 20 lag lenghts. The market liquidity and investor risk tolerance showed cointegration both in the developed and developing counrty markets. The variables have a long-run relation. 
The Investor Risk Tolerance and Market Liquidity Connection:

Evidence from the Selected Markets

\subsection{Pesaran CCE (Cointegration Coefficient Estimator)}

The cointegration coefficient estimators may be used to make comparison between groups and to determine the degree of the relationship. While cointegration and causality tests are useful for detecting the existence of relationships, they do not provide any information about the degrees (Güriş, 2018).

Cross-section dependency was found in the variable series. The Pesaran CCE (2006) can find accurate results even if the cross-sectional dependency and in heterogeneous series (Güriş, 2018).Therefore, the Pesaran CCE was applied at 90\%, 95\%, and 99\% confidence intervals. The test results are presented in the Table 6 for the developed country markets.

Table 6. Pesaran CCE Test Results for Developed Country Markets

\begin{tabular}{lrr}
\hline Country & Cointegration Coefficient & Probability \\
\hline Germany & -0.006 & 0.433 \\
USA & $* * 0.016$ & 0.031 \\
France & 0.000 & 0.948 \\
Japon & -0.000 & 0.977 \\
Italy & -0.001 & 0.228 \\
Canada & -0.001 & 0.107 \\
UK & $* * * 0.001$ & 0.009 \\
\hline$* * *, * * *$ denotes significance at the $1 \%, 5 \%$ and $10 \%$ level, respectively.
\end{tabular}

The cointegration coefficient could be estimated just for the USA at $95 \%$ and for the UK at $99 \%$ confidence interval (with 0.05 and 0.01 significance level, respectively). The test results showed that $1 \%$ increase (decrease) of the risk tolerance causes a rise (decreasing) approximately $1.60 \%$ for the USA market liquidity and $0.1 \%$ for the UK market liquidity. Neverthlessly, the cointegration coefficients could not be estimated for Germany, France, Japan, Italy and Canada markets at the mentioned confidence intervals.

Table 7. Pesaran CCE Test Results for Developing Country Market

\begin{tabular}{|c|c|c|}
\hline Country & Cointegration Coefficient & Probability \\
\hline China & 0.001 & 0.136 \\
\hline Indonesia & $* *_{-} 0.003$ & 0.042 \\
\hline Turkey & 0.000 & 0.691 \\
\hline Brazil & 0.000 & 0.546 \\
\hline India & -0.000 & 0.854 \\
\hline South Africa & 0.000 & 0.529 \\
\hline
\end{tabular}

Table 7 shows the Pesaran CCE test results for the developing countries. Similiarly, the cointegration coefficients could be estimated only for Indonesia (at 95\% confidence intervals) in the developing country markets. The market liquidity and risk tolerance showed an inverse relation in the Indonesian market. When the risk tolerance increase by $1 \%$ (decrease), the market liquidity will decrease (increase) by $0.3 \%$ in the market. The cointegration coefficient could not be estimated for the China, Turkey, Brazil, India and South Africa at the confidence intervals.

\subsection{Dumitrescu\& Hurlin (DH) Causality Test}

The causality tests give information about which variable is reason of the variable. It is helpful to understand the relation of the variables. In this study, the variables have cross-sectional dependency, therefore Dumitrescu and Hurlin (DH) (2012) causality test was preffered, because $\mathrm{DH}$ gives accurate results even in the unbalanced panels, cross-sectional dependency, 
heterogeneous lag-length panels or with wrong lag-lengths (Bozoklu and Y1lanc1, 2013). The table 8 shows the DH causality test results at the $95 \%$ confidence interval.

Table 8. DH Causality Test Results

\begin{tabular}{|c|c|c|c|c|}
\hline & \multicolumn{2}{|c|}{$\begin{array}{c}H_{0}: \text { no causality from tolerance } \\
\text { to liquidity }\end{array}$} & \multicolumn{2}{|c|}{$\begin{array}{c}H_{0}: \text { no causality from liquidity } \\
\text { to tolerance }\end{array}$} \\
\hline & Z-stat. & P-value & Z-stat. & P-value \\
\hline Developed Country Markets & 0.011 & 0.990 & 0.661 & 0.508 \\
\hline Developing Country Markets & 0.574 & 0.565 & -0.894 & 0.371 \\
\hline
\end{tabular}

One-way and two-ways causalities were tested. The developed country markets' $\mathrm{p}$ value is 0.990 for causality from the risk tolerance to the market liquidity and it is 0.508 for causality from the liquidity to the tolerance. The $\mathrm{H}_{0}$ of the DH test was not rejected. No any kinds of the causality were found between the variables. Similarly, $\mathrm{H}_{0}$ was not rejected for the developing country markets.

The $\mathrm{p}$ value is 0.565 for causality from the tolerance to the liquidity and 0.371 for causality from the liquidity to the tolerance. The results showed there is no causality between the variables.

\section{DISCUSSION}

The market liquidities were measured with the Amihud (2002) illiquidity ratio. It has been observed that the liquidity levels were low both in the markets of the developed and developing countries. Furthermore, all the markets have their own market liquidity and risk tolerance trends, the liquidity and tolerance do not move together with their market sample groups.

The series have cross-section dependency, auto-correlation, and variance problems.The cointegration test, causality test and cointegration coefficient estimator test were selected which takes attention the mentioned problems in the series. The econometric analysis results are listed in the below.

1. A cointegration was found between the variables.

The Westerlund (2006) cointegration test revealed $\mathrm{H}_{1}$ which states a relationship between the market liquidity and investors' risk tolerance should be accepted. The variables move together in the long-run and there is a relationship between them. That result is similar with studies of Kumar and Lee (2006), Baker and Wurgler (2006), Canbaş and Kandır (2009), Barber et al. (2009), Lin (2011), Yıldırım (2011), Garcia (2013) and Liu (2015).

2. The markets' cointegration regression coefficients are different.

The Pesaran (2006) CCE test showed similiar results with Y1ldırım (2011), Liu (2015) and Dahir et al. (2018)' s results. That test found cointegration coefficients are different in the markets and $\mathrm{H}_{5}$ is accepted.

The coefficient could be estimated just for the USA and Indonesia at 95\% confidence interval and for the UK at 99\% confidence interval. The cointegration coefficients are for the USA, the UK and Indonesia respectively $1.6 \%, 0.1 \%,-0.3 \%$. The market liquidity and investor risk tolerance have a positive relation in the USA and the UK, yet there is an inverse relation in the Indonesia. That means $1 \%$ increase (decrease) in the investor risk tolerance will be reason of the increasing (decreasing) in the market liquidity by $1.6 \%$ for the USA, $0.1 \%$ for the UK and decrease (increase) by $0.3 \%$ in Indonesia's market liquidity. The $\mathrm{H}_{5 \mathrm{a}}$ was accepted and $\mathrm{H}_{5 \mathrm{~b}}$ was not accepted.

The cointegration coefficients are positive for the USA and UK, but it is negative for the Indonesia. The cointegration coefficient could not be estimated for Germany, France, Japan, Italy and 
The Investor Risk Tolerance and Market Liquidity Connection: Evidence from the Selected Markets

Canada in the developed countries and for Turkey, China, Brazil, India and the South Africa in the developing countries at the specified confidence intervals.

3. No causality between the market liquidity and investor risk tolerance.

The DH (2012) panel causality test concluded no causality relationship between the market liquidity and investor risk tolerances. So, the market liquidity is not the reason of the investor risk tolerance, as well as the investor risk tolerance is not reason of the market liquidity. $\mathrm{H}_{2}$ and $\mathrm{H}_{3}$ were not accepted.

The DH (2012) causality test result contradicts to existing studies in the literature. Subrahmanyam (1991), Lee et al.(1991), Baker and Wurgler (2006), Kumar and Lee (2006), Canbaş and Kandır (2009), Barber et al. (2009), Lin (2011), Garcia (2013) and Liu (2015) stated that risk attitudes cause changes in the market liquidity and Y1ldirım (2011) mentioned the market liquidity affects the risk tolerance.

While there is no causality relationship between the variables, the existence of the cointegration implies some other variable(s) causes a relationship between the liquidity and tolerance. Additionally, the existence of heteroscedasticity in the series supports that possibility.

The variable(s) may be the global developments in stock markets (Hacihasanoğlu and Soytaş 2009), positive future expectations (Tetlock, 2007), market prices and returns (Canbaş and Kandir, 2009), costs in markets (Arrondel et al., 2010) and/or price volatility (Deuskar and Johnson, 2011).

\section{CONCLUSIONS}

This study has some remarkable results. First at all, the results revealed the relation degrees of the risk tolerance and market liquidity are not same in the overall sample. The cointegration coefficients could be estimated for just three of the thirteen markets (the USA, UK and Indonesia) at specified confidence intervals. Moreover, the relation is inverse in Indonesia whereas the coefficients are positive in the USA and UK. So, it was concluded the relationship between the risk tolerance and market liquidity are not same in the developed and developing countries.

Secondly, the cointegration and causality tests' converse results showed that the investors' risk levels may not directly affect the market liquidity. A long-term relation was found between the variables in the cointegration test. So, naturally a short-term relation was expected, but the causality test showed there are no any kinds of causalities between the variables. That means some other variable(s) may serve a long-term relation between the tolerance and liquidity. Heteroscedastacity problem of the series supports that possibility, as well. Researchers may find that result interesting because there is no any other studies point out that kind of result.

The previous studies support the idea that investors' risk tolerance directly can change the financial markets' liquidity levels. However, our results showed it also possible the variables do not have any power on each others as thought. After that, finding which and how a variable can cause a relation between the tolerance and liquidity will be important for the researchers. It is also important for the investors and financial markets. Because, forecasting the market liquidity will be easier and making investment decisions will be more effective by monitoring the variables. Additionally, taking attention to variety of cointegration coefficients may be helpful to manage investments in the markets and to understand how to react the financial market investors in the developed and developing countries. 
This study may inspire new researches by asking two questions. The first question is "which variable(s) does cause a long-term relation between the market liquidity and risk tolerance?" and the second question is "why the possible variable(s) does cause an inverse relation in the developing countries, while the relation is not inverse in the developed countries?" Those two questions are important for future studies to understand the variables' relation. Also, this study can be tested again by expanding the sample group or creating different sample groups in the future studies.

Peer-review: Externally peer-reviewed.

Conflict of Interest: The author declare that there is no conflict of interest.

Funding: The author received no financial support for the research, authorship and/or publication of this article.

Ethical Approval: This article does not contain any studies with human participants or animals performed by the author.

Author Contributions: Gonul Cifci(60\%) and Sukriye Gul Reis(40\%)

\section{REFERENCES}

Ajina, A., Lakhal, F. and Sougne D. (2015). Institutional investors, information asymmetry and stock market liquidity in France. International Journal of Managerial Finance 11(1), 44-59. doi: 10.1108/IJMF-08-2013-0086

Amihud, Y. (2002). Illiquidity and stock returns: cross-section and time-series effects. Journal of Financial Markets, 5(1), 31-56. Retrieved from: https://www.researchgate.net/profile/ Yakov-Amihud/publication

Apergis, N., Cooray, A. and Rehman, M.U. (2017). Do energy prices affect U.S. investor sentiment?. Journal of Behavioral Finance, 19(2), 125-140. doi:10.1080/15427560. 2017.1373354.

Arrondel, L., Pardo, H.C. and Oliver, X. (2010). Temperance in stock market participation: evidence from France. Economica, 77, 314-333. doi: 10.1111/j.1468-0335.2008.00733.x

Ausburg, G.B. and Spremann, U.K. (1981). Implications of constant risk aversion. Zeitschrift fiir Operations Research, 25, 205-224. Retrieved from: https://www.alexandria.unisg.ch/ publications / 50548

Baker, M. and Wurgler, J. (2006). Investor sentiment and the cross-section of stock return. The Journal of Finance, 61 (4), 1645-1680. doi: 10.1111/j.1540-6261.2006.00885.x

Baltagi, B.H. and Wu, P.X. (1999). Unequally spaced panel data regressions with AR(1) Disturbances. Econometric Theory, 15, 814-823. Retrieved from:https://www. researchgate.net/profile/Badi-Baltagi 2/publication/23564618

Bannier, C. E. and Neubert, M. (2016). Gender differences in financial risk taking: the role of financial literacy and risk tolerance. Economics Letters, 145, 130-135. doi:10.1016/ j.econlet.2016.05.033.

Barasinska, N. and Schafer, D. (2017). Gender role asymmetry and stock market participationevidence from four European household surveys. The European Journal of Finance, 1-27. doi:10.1080/1351847X.2017.1371622.

Barber, M.B., Odean, T. and Zhu, N. (2009). Systematic noise. Journal of Financial Markets, 12, 547-569. Retrieved from: http://citeseerx.ist.psu.edu/viewdoc 
The Investor Risk Tolerance and Market Liquidity Connection: Evidence from the Selected Markets

Bernoulli, D. "Specimen Theoriae Novae de Mensura Sortis”. Commentarii Academiae Scientiarum Imperialis Petropolitanae, 5(1738), 175-192. Translated by L. Sommer as "Exposition of a New Theory on the Measurement of Risk," Econometrica, 22(1), 23-36. 1954. Retrieved from: http:/ /www.jstor.org/stable/1909829?origin=JSTOR-pdf

Bernstein, L.P. (2015). Against the Gods: The remarkeable story of risk. New York: John Wiley\& Sons, Inc.

Bhargava, A., Franzini, L. and Narendranathan, W.M. (1982). Serial correlation and the fixed effects model. The Review of Economic Studies, 49 (4), 533-549. doi: 10.2307/2297285

Black, F. (1986). Noise. The Journal of Finance, 16(3), 529-543. Retrieved from: https://finpko.ku.edu/myssi/FIN938/Black. Noise. JF_ 1986. pdf

Blanchett D., Finke, M. and Guillemette, M. (2018). The effect of advanced age and equity values on risk preferences, Journal of Behavioral Finance, 19(4), 434-441. doi: 10.1080/15427560.2018.1431884.

Bozoklu, Ş. and Y1lanc1, V. (2013). The causality relation between financial development and economic growth: an analysis for emerging economies. Journal of Dokuz Eylul University Economic and Administrative Sciences Faculty, 28(2), 161-187.

Breusch, T. S. and Pagan, A.R. (1980). The Lagrange multiplier test and its applications to model specification in econometrics. The Review of Economic Studies, 47(1), 239-253. doi: $10.2307 / 2297111$

Brown, M.B. and Forsythe, A.B. (1974). Robust tests for the equality of variances. Journal of the American Statistical Association, 69, 364-367. doi:10.1080/01621459.1974.10482955

Canbaş, S. and Kandır, S. (2009). Investor sentiment and stock returns: evidence from Turkey. Emerging Markets Finance and Trade, 45(4), 36-52. doi:10.2753/REE1540-496X450403

Castagna, A. and Fede, F. (2013). Measuring and managing liquidity risk. Croydon: John Wiley\& Sons Inc.

Cheng, P.K. and Kim, Y.S. (2017). Speculative bubbles and crashes: fundamentalists and positivefeedback trading. Cogent Economics and Finance, 5(13), 1-28. doi: 10.1080/23322039.2017.1381370.

Chiang, T.F. and Xiao, J.J. (2017). Household characteristics and the change of financial risk tolerance during the financial crisis in the United States. International Journal of Consumer Studies, 41, 484-493. doi:10.1111/ijcs. 12356

Chou, C.P. (2014).Influences of parental control and decision making on risk-taking behavior: a cross-cultural study in the U.S.A and Taiwan. PhD dissertation. University of California, NY USA. Retrieved from: https://escholarship.org/uc/item/4sg9571t

Correa, R. Goldberg, L.S. and Rice, T. (2015). International banking and liquidity risk transmission: evidence from the United States. IMF. Economic Review, 63(3), 626-643. Retrieved from: https://www.jstor.org/stable/24738106

Coudert, V. and Gex, M. (2006). Can risk aversion indicators anticipate financial crises. Financial Stability Review, 9, 67-88. Retrieved from: https://blocnotesdeleco.banquefrance.fr/sites/default/files/medias/documents/financial-stability-review-09_2006-12 
Cumming, D., Johan, S. and Dan, L. (2011). Exchange trading rules and stock market liquidity. Journal of Financial Economics, 99, 651-671. Retrieved from: https://core. ac.uk/download/pdf/37986171.pdf

Dahir, A.M., Mahat, F.B. and Ali, N.A. (2018). Funding liquidity risk and bank risk-taking in BRICS countries: an application of system GMM approach. International Journal of Emerging Markets, 13(1), 231-248. doi: 10.1108/IJoEM-03-2017-0086

Deuskar, P. and Johnson, T.C. (2011). Market liquidity and flow-driven risk. The Review of Financial Studies, 721-753. doi:10.1093/rfs/hhq132

Doğanay, M.A., and Değer, M.K. (2017). Foreign direct investments and export relations in emerging market economies: panel data cointegration analyses (1996-2014). Çankur Karatekin University Journal of the Faculty of Economics and Administrative Sciences, 7(2), 127-145. Retrieved from: https://dergipark.org.tr/en/download/article-file/387543

Dumas, B.,Kurshev, A. and Uppal, R. (2009). Equilibrium portfolio strategies in the presence of sentiment risk and excess volatility. The Journal of Finance, 64(2). Retrieved from: https://www.nber.org/system/files/working_papers/w13401/w13401.pdf

Dumitrescu, E.I. and Hurlin, C. (2012).Testing for granger non-causality in heterogeneous panels. Economic Modelling, 29(4), 1450-1460. Retrieved from: https://halshs.archivesouvertes.fr/halshs-00224434/document

Erataş, F., Nur, H.B. and Özçalık, M. (2013). The puzzle of Feldstein-Horioka evaluation of advanced economies: a panel data analysis. Cankir Karatekin University Journal of the Faculty of Economics and Administrative Sciences, 3(2), 18-33. Retrieved from: https://link.gale.com/apps/doc/A435002580

Ernst, C., S. Stange and Kaserer, C. (2009). Measuring market liquidity risk-which model works best. CEFS Working Paper Series, 2009(1), 1-29. Retrieved from: https://www.econstor. eu/ bitstream/10419/48418/1/60335307X.pdf

Fan, J. X. and Xiao, J.J. (2006). Cross-cultural differences in risk tolerance: a comparison between Chinese and Americans. Journal of Personal Finance, 5(3), 54-75.

Farboodi, M. and Veldkamp, L. (2017). Financial technology, unpredictability and illiquidity in the long run. Retrieved from: https://www.stern.nyu.edu/sites/default/files /assets/ documents/LongRunEvolution_Jan2017.pdf

Franklin, S.C. (2007). Regulatory focus and financial risk aversion. PhD dissertation. Columbia University, NY USA.

Frinjs, B., Gilbert, A., Lehnert, T. and Tourani-Rad, A. (2013). Uncertainty avoidance, risk tolerance and corporate takeover decisions. Journal of Banking\& Finance, 37, 2457-2471. doi:10.1016/j.jbankfin.2013.02.010

Froot, K.A. and O' Connell, P.G. (2003). The risk tolerance of international investors. National Bureau of Economic Research, W10157. doi: 10.3386/w10157.

Garcia, D. (2013). Sentiment during recessions. The Journal of Finance, 68(3), 1267-1300. doi: $10.1111 /$ jofi. 12027

Grable, J. (2000). Financial risk tolerance and additional factors that affect risk taking in everyday money matters. Journal of Business and Psychology, 14, 625. Retrieved from: 
The Investor Risk Tolerance and Market Liquidity Connection: Evidence from the Selected Markets

https://d1wqtxts 1xzle7.cloudfront.net/46283668/a_3A10229943149822016060690769-14e17qo

Güriş, S. (2018). Uygulamalt panel veri ekonometrisi(The applied panel data econometric). İstanbul: Der Kitapevi.

Hacıhasanoğlu, E. and Soytaş, U. (2009). The impact of global risk perceptions on emerging markets: the case of Turkey. The International Journal of Economic and Social Research, 5(1), 39-50. Retrieved from: https://dergipark.org.tr/en/download/article-file/69144

Hurley, P.R. (2005). An emprical investigation using a real options analysis framework for making the optimal allocations of financial resource and application to investment decisions under uncertainty. PhD dissertation. Renssealer Polytechnic Institue, NY-USA. Retrieved from: https:// www. proquest.com/ openview

International Money Funds. (2010). Global financial stability report; sovereigns, funding, systemic liquidity. Retrieved from: https://www.imf.org/en/Publications/GFSR/ Issues/2016/12/31/Sovereigns-Funding- and-Systemic-Liquidity

Jain, D. and Mandot, N. (2012). Impact of demographic factors on investment decision of investors in Rajasthan. International Refereed Research Journal, 3(2), 81-92. Retrieved from: https:/ / www.proquest.com/openview/13b2725200976d6fc724f77d8507aa60

Kahyaoğlu, M. B. (2011). Yatırım kararlarına etki eden çeşitli duygusal ve psikolojik faktörlere maruz kalma düzeyi üzerinde cinsiyetin rolü: IMMB bireysel hisse senedi yatırtmclları üzerine bir uygulama (The role of gender on the exposure level of various emotional and psychological factors that affecting investment decisions: a research on individual stock investors of IMKB). The International Journal of Economic and Social Research, 7(1), 29-51. Retrieved from: https://dergipark.org.tr/en/download/article-file/69185

Keynes, J.M. (1936). The general theory of employment, interest and money. London: Macmillan.

Kumar, A. and Lee, C.M. (2006). Retail investor sentiment and return comovements. The Journal of Finance, 61(5), 2451-2486. doi: 10.1111/j.1540-6261.2006.01063.x

Lee, C.M., Shleifer, A. and Thaler, R.H. (1991). Investor sentiment and the closed-end fund puzzle.The Journal of Finance, 46(1), 75-109. doi:10.2307/ 2328690

Levene, H. (1960). Robust test for equality of variances, contributions to probability and statistics: essays in honor of Harold Hotteling. Stanford University Press, 278-292.

Lin, M. (2011). Investor sentiment and the fragility of liquidity. doi:10.2139/ssrn.1956315.

Liu, S. (2015). Investor sentiment and stock market liquidity. Journal of Behavioral Finance, 16(1), 51-67. doi: 10.1080/15427560.2015.1000334

Markowitz, H. (1952). The utility of wealth. Journal of political Economy, 60(2), 151-158. Retrieved from: https://www.jstor.org/stable/ 1825964

Muktadir-Al-Mukit, D. (2020). Do sociodemographic factors have influence on risk tolerance level of stock market investors? An analysis from a developing country perspective. South Asian Journal of Business Studies. doi:10.1108/SAJBS-11-2019-0193.

Pesaran, M.H. (2006). Estimation and inference in large heterogeneous panels with a multifactor error structure. Econometrica, 74(4), 967-1012. Retrieved from: https://www.econstor. eu/bitstream/10419/18696/1/cesifo1_wp1331.pdf 
Reis, Pedro M.N. and Pinho, C. (2021). A reappraisal of the causal relationship between sentiment proxies and stock returns, Journal of Behavioral Finance, 22(4), 420-442, doi: 10.1080/15427560.2020.1792910.

Rui, M., Hamish, A.D. and Marshall, B.R. (2016). International stock market liquidity: a review. Managerial Finance, 42(2), 118-135. doi: 10.1108/MF-04-2015-0096

Saraç, T.B., İskenderoğlu, Ö. and Akdağ, S. (2016). Investigation of domestic and foreign investors' risk appetite: the case of Turkey. Sosyoekonomi, 24(30), 29-44. doi:10.17233/se.2016.10.002

Stange, S. (2009). Market Liquidity Risk. PhD dissertation. Technische Universität München, Münih Germany. Retrieved from: https://mediatum.ub.tum.de/doc/829354/829354.pdf

Subrahmanyam, A. (1991). Risk aversion, market liquidity and price efficiency. The Review of Financial Studies, 4(3), 417- 441. Retrieved from: http://m.e-m-h.org/Subr91a.pdf

Subramanian, A. and Jarrow, R.A. (2001). The liquidity discount. Mathematical Finance, 11(4), 447-474. Retrieved from: https://d1wqtxts1xzle7.cloudfront.net/70541708/14679965.0012420210929

Sun, M.U. (2016). Interaction among funding liquidity, liquidity creation and stock liquidity of banks: evidence from BRICS countries. Journal of Financial Regulation and Compliance, 24(4), 430-452. doi: 10.1108/JFRC-11-2015-0062

Swamy, Paravastu. A.V.B. (1970). Efficient inference in a random coefficient regression model. Econometrica, 38, 311-323. Retrieved from: http://links.jstor.org/sici

Tetlock, P.C. (2007). Giving content to investor sentiment the role of media in the stock market.The Journal of Finance, 62(3), 1139-1168. Retrieved from: https://d1wqtxts 1xzle7.cloudfront. net/51310263/TETLOCK

Tobin, J. (1958). Liquidity preference as behavior towards risk. The Review of Economic Studies, 26(1), 65-86. Retrieved from: https://www.jstor.org/stable/2296205

Usul, H., Bekçi, I. and Eroğlu, A. Hüsrev (2002). Bireysel yattrmmclların hisse senedi edinimine etki eden sosyo-ekonomik etkenler(The socio-economic factors' effects on the individual investors share investments). Erciyes University Journal of Economics and Administrative Sciences, 2002(19), 135-150. Retrieved from: https://dergipark.org.tr/en/download/ article-file/501673

Westerlund, J. (2006). Testing for panel cointegration with multiple structural breaks. Oxford Bulletin of Economics and Statistics, 68(1), 101-132. doi:10.1111/j.14680084.2006.00154.x

Yıldırım, B.D. (2011). Measuring and analyzing financial market liquidity of Turkey. Central Bank Review, 11, 11-28. Retrieved from: https://tcmb.gov.tr/wps/wcm/connect 
The Investor Risk Tolerance and Market Liquidity Connection: Evidence from the Selected Markets

\section{APPENDIX}

Appendix 1. Pesaran CADF Unit- Root Test Results

\begin{tabular}{|c|c|c|c|c|c|c|c|c|c|}
\hline \multirow[b]{3}{*}{ Variables } & & \multicolumn{4}{|c|}{ Developed Countries } & \multicolumn{4}{|c|}{ Developing Countries } \\
\hline & & \multicolumn{2}{|c|}{ With Constant } & \multicolumn{2}{|c|}{ With Constant\& Trend } & \multicolumn{2}{|c|}{ With Constant } & \multicolumn{2}{|c|}{ With Constant $\&$ Trend } \\
\hline & & t-value & Prob. & t-value & Prob. & t-value & Prob. & t-value & Prob. \\
\hline \multirow{2}{*}{$\begin{array}{l}\text { Market } \\
\text { Liquidity }\end{array}$} & level & 2.576 & 0.010 & 2.698 & 0.141 & 4.072 & 0.000 & 4.492 & 0.000 \\
\hline & first difference & 6.190 & 0.000 & -6.42 & 0.000 & 6.190 & 0.000 & 6.420 & 0.000 \\
\hline $\begin{array}{l}\text { Investor } \\
\text { Risk }\end{array}$ & level & 5.656 & 0.000 & 6.024 & 0.141 & -5.531 & 0.000 & -5.744 & 0.000 \\
\hline Tolerance & first difference & -6.190 & 0.000 & -6.420 & 0.000 & -6.190 & 0.000 & -6.420 & 0.000 \\
\hline
\end{tabular}

Appendix 2. Breusch-Pagan Cross- Section Dependency Test Results

\begin{tabular}{|c|c|c|c|c|c|c|c|c|c|c|}
\hline & \multirow[b]{3}{*}{ df } & \multirow{2}{*}{\multicolumn{2}{|c|}{$\begin{array}{r}\text { Developed } \\
\text { Market Liquidity }\end{array}$}} & \multirow{2}{*}{\multicolumn{3}{|c|}{$\begin{array}{l}\text { Countries } \\
\text { Investor Risk Tolerance }\end{array}$}} & \multicolumn{4}{|c|}{ Developing Countries } \\
\hline & & & & & & & Market L & iquidity & Investor Risk & lerance \\
\hline & & Statistic & Prob. & Statistic & Prob. & df & Statistic & Prob. & Statistic & Prob. \\
\hline Breusch-Pagan LM* & & 2863.474 & $* 0.000$ & 73.360 & *0.000 & & 1685.251 & $* 0.000$ & 19.473 & $* 0.193$ \\
\hline Pesaran scaled LM & & 438.603 & 0.000 & 8.079 & 0.000 & & 304.945 & 0.000 & 0.817 & 0.414 \\
\hline $\begin{array}{l}\text { Bias-corrected } \\
\text { scaled LM }\end{array}$ & 21 & 438.597 & 0.000 & 8.074 & 0.000 & 15 & 304.94 & 0.000 & 0.812 & 0.417 \\
\hline Pesaran CD & & 48.550 & 0.000 & -0.288 & 0.774 & & 40.451 & 0.000 & -0.232 & 0.816 \\
\hline
\end{tabular}

Appendix 3. Swamy-S Test of Homogeneity and Bhargava, Franzini and Narendranathan Autocorrelation Test Results

\begin{tabular}{|c|c|c|c|}
\hline \multirow[b]{2}{*}{ Test } & Developed Countries & \multicolumn{2}{|c|}{ Developing Countries } \\
\hline & Test Statistics $\quad P>z$ & Test Statistics & $\mathbf{P}>\mathbf{z}$ \\
\hline Swamy's Homogeneity & 2.07 & 0.24 & 0.62 \\
\hline \multicolumn{4}{|l|}{ Autocorrelation } \\
\hline$\overline{\text { Modified Bha. Durbin-Watson }}$ & 0.13 & 0.77 & \\
\hline Baltagi-Wu LBI & 0.15 & 0.79 & \\
\hline
\end{tabular}

Appendix 4. Heteroscedasticity Test Results

\begin{tabular}{lccc}
\hline TEST & $\begin{array}{c}\text { Developing } \\
\text { Test Stat. }\end{array}$ & $\begin{array}{c}\text { Countries } \\
\text { Prob }>\text { F }\end{array}$ & $\begin{array}{c}\text { Developed Countries } \\
\text { Test Stat. }\end{array}$ \\
\hline Wald Test & & & 170,000 \\
Levene, Brown, Forsythe Test & & & \\
$W_{0}$ & 11.32 & 0.00 & \\
$W_{50}$ & 11.28 & 0.00 & \\
$W_{10}$ & 11.31 & 0.00 & \\
\hline \hline
\end{tabular}




\section{GENIŞLETILMIŞ ÖZET}

\section{Araştırma Amacı}

Bu çalışma, gelişmiş ve gelişmekte olan ülkelerin sermaye piyasalarının likiditesi ile yatırımcı risk toleransının ne şekilde birbiri ile ilişkili olduğunu ve eğer ilişki söz konusu ise bu ilişkinin piyasalarda değişkenlik gösterip göstermediğini tespit etmeyi amaçlamaktadır.

\section{Araştırma Problemi}

Piyasa likiditesi ve yatırımcı risk toleransı arasındaki ilişkiyi irdeleyen bu çalışma değişkenler arasındaki ilişkiye dair dört soru yöneltmektedir; i.yatırımcıların risk toleransı ile piyasanın likiditesi arasında bir ilişki var mıdır?, ii. bu iki değişken arasındaki ilişki pozitif mi yoksa negatif yönlü bir ilişki midir?, iii. yatırımcı risk toleransı ile piyasa likiditesi arasındaki tek yönlü veya çift yönlü bir nedensellik ilişkisi var mıdır?, iv. yatırımcı risk toleransı ile piyasa likiditesi arasındaki ilişki piyasalararası farklılık göstermekte midir?. Bu sorular aracılı̆̆ıla piyasa likiditesi ve yatırımcı risk toleransı arasında bir ilişki var olup olmadığı, ilişki var ise bu ilişkinin yapısı ve ayrıca piyasalardaki farklılıkları hakkında bilgi edinilmiş olacaktır.

\section{Yöntem}

Araştırmada örneklem olarak Uluslararası Para Fonu (IMF)' nun ülkeler listesinden yedi gelişmiş ve altı gelişmekte olan ülke seçilmiştir. Bu ülkeler ve ülkelere ait piyasa endeksleri Tablo 1' de yer almaktadir.

Tablo 1. Örneklemde Yer Alan Ülkeler ve Piyasa Endeksleri

\begin{tabular}{llll}
\hline $\begin{array}{l}\text { Gelişmiş } \\
\text { Ülkeler }\end{array}$ & $\begin{array}{l}\text { Piyasa } \\
\text { Endeksi }\end{array}$ & $\begin{array}{l}\text { Gelişmekte } \\
\text { Olan Ülkeler }\end{array}$ & $\begin{array}{l}\text { Piyasa } \\
\text { Endeksi }\end{array}$ \\
\hline Kanada & S\&P/TSX Composite Index & Türkiye & BIST 100 \\
Japonya & NIKKIE 225 & Brezilya & IBOVESPA \\
Fransa & CAC 40 & Endonezya & JKLQ 45 \\
Almanya & DAX Performance Index & Hindistan & NIFTY 50 \\
İtalya & FTSE/MIB & Güney Afrika & FTSE/ JSE 40 \\
İngiltere & FTSE 100 & Çin & Shangai SE 50 \\
Amerika & NASDAQ 100 & & \\
\hline
\end{tabular}

Gelişmekte olan ülkeler için Türkiye, Brezilya, Endonezya, Hindistan, Güney Afrika ve Çin, gelişmiş ülkeler için ise İngiltere, Japonya, Amerika, Fransa, Almanya, İtalya ve Kanada örnekleme dahil edilmiştir. Örneklemde yer alan tüm piyasalar için 01/01/2008- 30/07/2019 tarih aralığında, haftalık bazda, piyasanın likidite düzeyi ve yatırımcı risk toleransı hesaplanmıştır. Bu veri serileri ekonometrik yöntemler ile test edilerek değişkenler arasındaki nedensellik ve eşbütünleşme ilişkileri irdelenmiştir. Ayrıca, bu ilişkinin piyasalarda farklı olup olmadığını tespit etmek amacıyla eşbütünleşme regresyon katsayı tahmincisi uygulanmıştır.

\section{Bulgular}

Uygulanan panel ekonometri testlerinin neticesinde tüm piyasalarda, yatırımc1 risk toleransı ile piyasa likiditesi arasında eşbütünleşmenin olduğu, değişkenlerin birlikte hareket ettiği bulunmuştur. Bu değişkenler arasında uzun dönemli bir ilişki olduğu anlamına gelmektedir. Piyasalararası farklılıkları ortaya koyabilmek amacıyla uygulanmış olan eşbütünleşme regresyon katsayısı tahmincisi sonuçları ise piyasalara göre farklılık göstermiştir. Bu test \%90, \%95 ve \%99 güven aralığında uygulanmıştır. Eşbütünleşme regresyon katsayısı belirlenmiş olan güven aralıkları içerisinde İngiltere, Amerika ve Endonezya olmak üzere üç ülke piyasası için tahmin edilebilmiştir. İngiltere için \%99 güven aralığında tahmin edilen katsayı \%0.01 olmuştur. Amerika için \%95 güven aralığında tahmin edilen katsayı \%1.6'dır. Endonezya' da ise negatif yönlü bir 
The Investor Risk Tolerance and Market Liquidity Connection: Evidence from the Selected Markets

ilişki bulunmuştur. Tahmin edilen eşbütünleşme regresyon katsayısı \%95 güven aralığında \%0.3'dır. Buna göre piyasa likiditesi \%1 artış (azalış) gösterdiğinde yatırımcıların risk toleransı İngiltere'de \% 0.01 artış (azalış), Amerika'da ise \% 1.6 artış (azalış) ve Endonezya'da \% 0.3 azalış (artış) gerçekleşecektir.

Risk toleransı ve piyasa likiditesi arasındaki nedensellik ilişkisi \%95 güven aralığı ile üç şekilde incelenmiştir. Bunlar; yatırımcı risk toleransından piyasa likiditesine nedensellik ve piyasa likiditesinden yatırımcı risk toleransına nedensellik şeklinde tek yönlü nedensellik ve değişkenler arasında çift yönlü nedensellik şeklindedir. Ancak değişkenler arasında tek yönlü veya çift yönlü herhangi bir nedensellik ilişkisi bulunamadığından değişkenler arasında kısa dönemli bir ilişkiden söz edilememektedir.

\section{Sonuç}

Yapılan eşbütünleşme testi sonucunda değişkenler arasında bir eşbütünleşme bulunmuş olup $\mathrm{H}_{1 b}$ hipotezi kabul edilmiştir. Değişkenler arasında uzun dönem ilişki gözlenmiştir. Ayrıca Amerika, Endonezya ve İngiltere için farklı güven aralıklarında eşbütünleşme regresyon katsayıları tahmin edilmiştir. Elde edilen katsayılara göre gelişmiş ülkeler içerisinde yer alan Amerika ve İngiltere' de artan piyasa likiditesi ile beraber yatırımcıların da risk toleranslarının arttığı, diğer yandan gelişmekte olan ülkelerden Endonezya'da yatırımcıların risk toleranslarının azaldığı sonucuna ulaşılmıştır. Elde edilen katsayılar farklılık göstermekte ve ayrıca değişkenler Endonezya' da ters yönlü, Amerika ve İngiltere' de ise doğrusal bir ilişki sergilemektedirler. Bu sonuçlara bağlı olarak $\mathrm{H}_{5}$ ve $\mathrm{H}_{5 a}$ hipotezleri kabul edilmiştir. Eşbütünleşme regresyon katsayıları belirlenmiş güven aralıklarında örneklem içerisinde yer alan diğer ülkelerin piyasaları için tahmin edilememiştir. Nedensellik testi sonuçları ise eşbütünleşme test sonucu ile uyuşmamaktadır. Değişkenler arasında herhangi bir nedensellik ilişkisi bulunamamıştır. Bu nedenle $\mathrm{H}_{2}$ ve $\mathrm{H}_{3}$ hipotezleri red edilmiştir. Değişkenler arasında uzun dönemli ilişki varken kısa dönemli bir ilişki söz konusu değildir. Ortaya çıkan bu sonuçlar değişkenler arasında ilişki sağlayan başka değişken veya değişkenlerin olabileceğini işaret etmektedir. Yatırımcı risk toleransı ve piyasa likidite serilerinde rastlanmış olan değişen varyans sorunu da bu sonucu destekler niteliktedir. Risk toleransı ve likidite arasında uzun dönemli ilişkiye yol açan bu değişkenin veya değişkenlerin piyasalar üzerindeki etkilerinin de farklı olduğu söylenebilir. Söz konusu değişken(ler) gelişmiş ülke piyasalarında pozitif bir ilişki sağlarken gelişmekte olan ülke piyasalarında negatif bir ilişki sağlamaktadır. 